\title{
ČESKÁ BIBLICKÁ PRÁCE V KUTNÉ HOŘE ${ }^{1}$
}

P AVEL J ÄGER

\section{1. Úvod}

K

tná Hora má pozoruhodnou biblickou tradici. Pojem „Kutnohorská bible“ je možno vyložit dvěma způsoby. Bud' si čtenář vybaví druhou tištěnou českou bibli Martina z Tišnova z roku 1489, anebo přetisk (o sto let mladšího) prvního vydání Bible kralické publikovaný v Kutné Hoře $\mathrm{v}$ roce 1940 . V roce 2009 byla věnována obšírná pozornost zmiňované bibli z konce 15. století, při př́ležitosti 520. výročí jejího vydání. Slušelo by se tedy nyní připomenout i další shora zmíněné dílo. Šlo o nejvýznamnější počin malé (nejen) nakladatelské společnosti. Poslání kutnohorské České biblické práce bylo zejména vedeno evangelizačním či misijním duchem. Z tohoto úhlu pohledu třeba hodnotit i její činnost, která trvala poměrně krátce. Mezi jejími spolupracovníky sice nenalezneme osobnosti univerzitního světa, přesto dokázali svoji dosaženou erudici využít výjimečným způsobem.

Pro vyjasnění základních pojmů je třeba zejména říci, že kutnohorská Česká biblická práce a Biblická společnost britická a zahraničnív Praze (v první polovině 20. století vícekrát změnila název) jsou organizace svým působením dost odlišné. Biblická společnost měla za své výhradní poslání rozšiřrovat Písmo sv. po celém světě. Svůj pražský sklad knih založila už v roce 1865. Tato (nekatolická) společnost musela pro svoji činnost nechávat tisknout české bible $\mathrm{v}$ cizině. Jako předlohu si zvolila upravené vydání Bible kralické z roku 1613. Po vzniku Československa se její pražský sklad přeměnil roku 1920 na již samostatnou národní pobočku této mezinárodní společnosti. Jejím předsedou byl tehdy zvolen zasloužilý kolportér Jindřich Špaček. ${ }^{2}$

1 Šetření dobového pozadí recepce biblického textu v nekatolickém prostředí vzniklo v rámci plnění grantového projektu „Biblista Jan Nepomuk Hejčl (1868-1935)“, GA UK č. 77310.

2 K jeho osobě a počátkům biblické společnosti v Čechách srov. ŠPAČEK, Jindřich. Vzpominky biblického kolportéra. Praha: Česká biblická společnost, 2008. 
Př́tomnost nadnárodní společnosti na českém území vedla později u komunistického vedení státu $\mathrm{k}$ nelibosti. $\mathrm{Z}$ politických důvodů se tak musela v roce 1949 přeměnit na Biblickou společnost československou. K poslednímu lednu 1953 pak byla pod nátlakem zrušena. ${ }^{3}$ Obnovena byla teprve po roce 1990 .

\section{Vznik a poslání}

Česká biblická práce v Kutné Hoře vznikla za poněkud jiným účelem: „povznésti mravní úroveň našeho národa v duchu biblickém“.4 Toto poslání vyplynulo z nadšení a činnosti několika pražských a kutnohorských členů Jednoty českobratrské. ${ }^{5}$ Spolek byl založen při schůzi př́pravného výboru 30. května 1929 pod názvem Biblická práce (teprve později byl přijat název Česká biblická práce, ČBP). ${ }^{6}$ Prvním předsedou se stal František Urbánek. ${ }^{7}$ Zanedlouho byl v roce 1931 na toto místo zvolen Zdeněk Koukol, majitel kutnohorské čokoládovny Lidka. ${ }^{8}$ Byla to právě osobnost

3 Srov. ŽILKA, Ladislav. Česká biblická společnost. Praha: Česká biblická společnost, 2003, s. 9.

4 Stanovy, odst. II., čj. I-6-6094-1947, fČBP. Není-li uvedeno jinak, archivní materiály jsou čerpány z pěti kartonů neuspořádaného fondu České biblické práce ve Státním okresním archivu Kutná Hora (fČBP). Část materiálů, zvláště k práci prof. J. Roháčka, je prozatímně uložena v neuspořádaném sborovém archivu církve bratrské v Kutné Hoře (fSCB). Cennými vzpomínkami mi pomohl prof. Pavel Chráska, syn dále zmiňovaného dr. Pavla Chrásky. Za rozhovory a zapůjčení Knihy zápisů ČBP mu tímto děkuji.

5 Srov. Zápis z valné schůze 2. června 1951. In Kniha zápisů ČBP. Jednota českobratrská v roce 1967 přijala označení Církev bratrská.

6 Srov. CHRÁSKA, Pavel. Česká biblická práce. Brána 2009, č. 5-6, s. 30. Srov. Zápis ze schůze dne 30. května 1929. In Kniha zápisů ČBP. Plným názvem Biblická práce Jednoty Českobratrské se sídlem v Praze. - Změna názvu na Česká biblická práce se sídlem v Praze byla odhlasována na schůzi 8. listopadu 1936. Pro zjednodušení bude v celém článku použita jednotná zkratka ČBP.

7 František Urbánek (1866-1948) maturoval v Praze v roce 1885. Teologii studoval ve Vídni, Lipsku (přednášky hebraisty prof. Franze Delitzsche), Halle a v Berlíně. Po zakončení studií (1890) chtěl vyučovat, ale vážné problémy s plícemi mu znemožňovaly veřejné přednášky. Během kazatelského působení pracoval v několika sborech, byl i členem Rady Jednoty českobratrské. S kazatelem Aloisem Adlofem měli zásadní vliv na vývoj Jednoty. Působil i v charitativní oblasti. Stal se blízkým přítelem Tomáše G. Masaryka a celé jeho rodiny. Byl u pohřbu prezidenta (1937), jeho manželky (1923) a obou synů $(1915,1948)$. Ke vztahu Urbánek-Masaryk viz DVOŘÁKOVÁ, Jana. Církev bratrská v době nacistické okupace. Obhájená diplomová práce na Filozofické fakultě Masarykovy univerzity v Brně. Brno, 2007, s. 17.

8 Srov. CHRÁSKA, Pavel. Česká biblická práce, s. 30. Zdeněk Koukol (1882-1953) byl spolumajitel čokoládovny Lidka - Koukol a Michera v Kutné Hoře. Udržoval čilé kontakty s podniky ve většině evropských států i Blízkého Východu. V rámci Jednoty českobratrské byl členem Rady a v Kutné Hoře pomáhal zakládat místní sbor. Za války sám kolportoval bible a inicioval vznik Biblického ústavu (1946). 
podnikatele Z. Koukola, která od počátku administrativně i materiálně významně podporovala činnost ČBP. ${ }^{9}$ Svá velká poslání chtěla ČBP naplňovat vydáváním a rozšiřováním biblí, biblických knih, drobnějších spisů, letáků, či plakátů s biblickými verši. Nový ředitel kolem sebe shromáždil skupinu vzdělaných lidí, kteří byli ochotni věnovat svůj čas i peníze společné věci. ${ }^{10}$ Činnost spolku se nikdy nechápala jako výdělečná. Je důležité poznamenat, že kromě později placených kolportérů, pracovali všichni zdarma. ${ }^{11}$ Rozšiřování Božího slova mezi lidi má v sobě jiný zisk, než ten finanční. Výdaje společnost pokrývala osobními dary podporovatelů nebo sbírkami z ostatních sborů Jednoty. ${ }^{12}$ Významným způsobem pomáhala Scripture Gift Mission. ${ }^{13}$ Již v září 1929 darovala začínající společnosti 1000 Nových zákonů. ${ }^{14}$

Velká část celkové produkce se rozdávala zcela zdarma. Ústřední matici školské, spolku, jehož náplní byla podpora základního školství v jazykově smíšených oblastech, darovala ČBP větší počet českých biblí. ${ }^{15}$ Rusky mluvícím pravoslavným věřícím na Slovensku darovala řadu Nových zákonů a evangeliî. ${ }^{16} \mathrm{~V}$ roce 1949 daroval spolek velké množství biblí pro knihovny mužských věznic a krajskou soudní věznici v Praze. ${ }^{17}$ Různých evangelizačních letáčků se rozšiřovaly desetitisíce ročně.

\section{Vzdělávací činnost}

Úkol „povznésti ducha národa“ ČBP plnila také pořádáním populárně naučných přednášek a kurzů. Zajímavým počinem bylo v roce 1936 pozvání mladého misionáře, bývalého skotského fotbalového reprezentanta Ja-

9 Srov. DVOŘ́́KOVÁ, Jana. Církev bratrská v době nacistické okupace, s. 29. Zakládající schůzi dne 30. května 1929 se zavázal darovat ročně $10000 \mathrm{~K}$. Srov. Zápis ze schůze dne 30. května 1929. In Kniha zápisů ČBP.

10 Zmiňme některé pozdější spolupracovníky: dr. Pavel Josef Chráska, Václav Svoboda, Josef Pavel, Pavel Just, Bohuslav Zrůst, Jindřich Špaček, František Chládek, Bohumil Mikulecký a František Urbánek. Většina z nich pocházela z Kutné Hory a okolí.

11 První kolportér, bratr Matěj působící v okolí Ostravy, byl přijat v říjnu 1929, ale nebyl zcela dobrou volbou. Nespolupracoval s vedením ČBP podle jejích představ, a proto musel být v květnu 1931 propuštěn. Srov. Zápis ze schůze ze dne 30. dubna 1931. In Kniha zápisů ČBP.

12 V prvních zápisech schůzí ČBP jsou poznámky, že např. žižkovský nebo brněnský sbor se zavázal věnovat $300 \mathrm{~K}$ měsíčně.

13 Londýnská společnost Scripture Gift Mission (ve zkratce SGM) byla založena v roce 1888 Williamem Waltersem. Zdarma rozdávala celé bible nebo její části a různé letáky zaměřené rovněž na četbu Písma.

14 Srov. Zápis ze schůze dne 27. září 1929. In Kniha zápisů ČBP.

15 Srov. Dopis Ústřední matice školské ze dne 20. ledna 1947, fSCB.

16 Srov. Dopis Eparchiální rady pravoslavné církve ze dne 7. května 1947, fSCB.

17 Srov. Dopis B. K. Radechovského ze dne 15. července 1949, fSCB. 
mese Stewarta, který s velkým ohlasem vystoupil v Praze. ${ }^{18}$ Na Slovanském ostrově přednesl ve dnech 9.-11. listopadu 1936 tři proslovy, které podle dochovaných zpráv poslouchalo 3500 lidí. ${ }^{19}$ Dále můžeme zmínit pravidelné pořádání biblických kurzů. Začaly se pořádat v době, kdy bylo ve válečném období znemožněno řádné studium kandidátů kazatelské služby, avšak nebyly určeny výhradně pro ně. ${ }^{20}$ První kurz na náklad kutnohorské ČBP se uskutečnil v roce $1939 .{ }^{21}$ Pravidelně se jednalo o týden z kraje července a účastnilo se ho až dvě stě posluchačů z celého protektorátu.

Na vzdělávací přednášky a kurzy později navázal Biblický ústav, který sloužil ke vzdělání kazatelů, misionářů a jiných biblických pracovníků. ${ }^{22}$ Vznikl z iniciativy Zdeňka Koukola. ${ }^{23}$ Vyučovat se začalo 10. listopadu 1947. Škola měla být otevřená členům všech reformačních církví i všech slovanských národů. $O$ přijetí studentů ke studiu rozhodovala a měla poslední slovo rada církve. Sbor přednášejících byl převážně složen z odborníků a kazatelů Jednoty. Pastorační předměty vyučoval František Urbánek, biblický výklad František Zdychynec, ${ }^{24}$ dogmatiku Bohuslav Beneš ${ }^{25}$ církevní dějiny a filozofii dr. Adolf Pospíšil z Brna, ${ }^{26}$ dějiny

18 James Alexander Stewart (1910-1975) skotský fotbalista a horlivý misionář. Během svých evangelizačních cest procestoval Litvu, Estonsko i Polsko. V Americe později založil nakladatelství. Srov. Twentieth Century Revivals. <http://www.revival -library.org/catalogues/20thcentury/index20thcentury.html >.

19 STEWART, James. Mé svédectví. Praha: Křestanský spolek mladíků v Čechách, 1936.

20 Srov. DVOŘÁKOVÁ, Jana. Cirkev bratrská v době nacistické okupace, s. 58.

21 Srov. CHRÁSKA, Pavel. Česká biblická práce, s. 31. Srov. KOUKOL, Zdeněk. Vznik Biblického ústavu v Kutné Hoře. In Kronika Biblického ústavu (rukopis), Archiv Rady církve bratrské (ARCB), s. 3.

22 Srov. PROKOP, Miloš. Z kroniky. Listy sboru CB v Kyjově, listopad 2007. Srov. KOUKOL, Zdeněk. Vznik Biblického ústavu v Kutné Hoře, s. 2.

23 Srov. KOUKOL, Zdeněk. Vznik Biblického ústavu v Kutné Hoře, s. 3.

24 František Zdychynec (1889-1954) po maturitě v Prachaticích odešel studoval teologii do Halle a Edinburghu (nedokončil studium filosofie v Praze). Byl téměř po celou dobu existence Českobratrské rodiny (1925-1951) jejím redaktorem. Působil i v jiných časopisech. Byl dlouholetým členem Rady Jednoty. Na Vinohradech vedl biblické kurzy; po zřízení Biblického ústavu vyučoval v Kutné Hoře.

25 Bohuslav Beneš (1908-1989) vystudoval Husovu čsl. bohosloveckou fakultu v Praze (1929-1933). Další vzdělání získal ve Švýcarsku, Německu a Skotsku. Po smrti F. Zdychynce (1954) byl dlouholetým předsedou Rady Jednoty (resp. Rady církve bratrské - po přijetí nového názvu církve v r. 1967). Během jeho působení došlo pod nátlakem státu ke zrušení Biblického ústavu i ČBP v Kutné Hoře. V roce 1969 dostal čestný doktorát teologie. Adolf Pospíšil (1904-1967) začal studovat na Husově čsl. bohoslovecké fakultě v Praze (1926), později v Zürichu, Basileji a Vídni. Během kazatelského působení získal doktorát filosofie na univerzitě v Brně (1937). V roce 1945 byl předsedou revolučního národního výboru v Německém Sněžném (po 1945 přejmenováno na Sněžné), kde působil jako kazatel, než odešel do Brna. 
misie, pedagogiku, ruštinu a němčinu první ředitel školy dr. Karel Kolman, ${ }^{27}$ češtinu dr. Samuel Verner, ${ }^{28}$ řečtinu s angličtinou kutnohorský dr. Pavel Chráska, ${ }^{29}$ hudbu a zpěv Jan Valach a hebrejštinu dr. Josef Berka, ${ }^{30}$ který později přeložil První knihu Mojžíšovu.

V roce 1948 přešla správa školy přímo pod Jednotu českobratrskou. Vládním nařízením č. 121/1950 Sb. ze dne 14. července 1950 byl ústav $\mathrm{s}$ jednadvaceti studenty zrušen. ${ }^{31}$ Vzdělávací biblické kurzy u Hrubé Lhoty probíhaly až do roku $1953 .^{32}$

\section{Produkce biblické literatury}

Přechod od téměř výhradně distribuční a přednáškové činnosti k náročnější nakladatelské nastal příchodem dr. Pavla Chrásky do Kutné Hory v polovině třicátých let. Nejvýraznějším počinem ČBP bylo bezesporu vydání Písma sv. vlastním nákladem. $\mathrm{O}$ to významnější, že v celé zemi byl v té době nedostatek papíru. Z iniciativy dr. Josefa Berky se začal rodit zcela nový překlad Starého zákona. Práce to však nebyla zásadně novátorská a mezi čtenáři nezpůsobila velký ohlas. Třetí významný počin, důležitý pro slovenské věřící, bylo vydání revidovaného překladu prof. Jozefa Ro-

27 Karel Kolman (1892-1962) absolvoval učitelský ústav v Mokré (Slovensko), kde následně i vyučoval na školách. V roce 1928 přešel do měštanské školy v Trhovém Štěpánově. Byl prvním ředitelem Biblického ústavu. Kvůli tomu podnikl mezi ř́jnem 1946 a létem 1947 poznávací cestu po evropských biblických školách ve Skotsku, Anglii, Francii, Švýcarsku i Německu. Později se vrátil do Trhového Štěpánova. Srov. $<$ http://www.knihovnavlasim.cz/region_autori_K-N.htm>.

28 Samuel Verner (1897-1976) byl básníkem a knihovníkem. Podílel se na revizi bratrského Krestáanského kancionálu (1930). Ještě znatelněji je znát jeho vliv na čtvrtém upraveném vydání (1965). Přeložil nebo sám sepsal některé písně (např. texty Dnes jásejte, vérní či Bud' tobě sláva). Přátelil se s katolickým autorem Jakubem Demlem. Antonín Chráska se k němu vyjadřuje rezervovaně: „Dr. Verner veršuje, ale ne vždy se mu to podaří - aspoň není to vždy dle mé chuti.“ Srov. Dopis Antonína Chrásky ze dne 31. ledna 1938, fSCB.

29 Pavel Chráska (1904-1971), syn Antonína Chrásky, po maturitě studoval teologii v Praze na evangelické bohoslovecké fakultě a ve Skotsku. Zároveň studoval na pražské filosofické fakultě historii. Když nemohl nalézt odpovídající práci, Zdeněk Koukol mu v roce 1932 nabídl místo v čokoládovně v Kutné Hoře.

30 Josef Berka (1886-1964), kazatel a archivář, studoval teologii na univerzitě v Halle (1909-1911) a ve Vídni (1911-1912). Ve Vídni vyučoval na české škole a později opět studoval, prehistorii a semitské jazyky (1923-1926). Od roku 1928 žil v Berouně, kde nejdříve vyučoval na měštanské škole a pak působil v městském a okresním archivu (od 1952).

31 Srov. NOVOTNÝ, Vojtěch. Katolická teologická fakulta 1939-1990. Praha: Karolinum, 2007, s. 84-86. Na tuto školu dnes navazuje Evangelikální teologický seminár Vyšši odborná škola teologická a sociálnív Praze (http://etspraha.cz/).

32 Podle ústního sdělení prof. Pavla Chrásky. 
háčka. O překlady zvláště životopisných brožurek významných osobností evropské reformované církve 18.-19. století se ve spolupráci s jinými staral Václav Svoboda. Jak již bylo řečeno, ČBP nevydávala tisky pouze v českém jazyce - většího nákladu se dočkal slovinský překlad Lukášova evangelia a celého Nového zákona od Antonína Chrásky. ${ }^{33}$

\section{Bible kralická 1579-1593}

S určitou nadsázkou můžeme říci, že pro české evangelíky se Bible kralická stala určitým pojítkem a bytostným znakem konfesijní příslušnosti. Tato bible byla po celá staletí od svého vzniku symbolem všech útrap svých držitelů. V katolické církvi však tento překlad nenašel uplatnění. Bible kralická objektivně nesplňovala parametry vymezené církevními předpisy, a není se tedy čemu divit, že státní i církevní cenzura dlouho nedovolovaly tisk tohoto pro evangelíky tak prestižního díla. Proto bylo nutné výtisky Bible kralické dovážet ze zahraničí. Bibli kralickou tiskla řadu let téměř výhradně Biblická společnost britická a zahraniční, a to ve verzi držící se v podstatě vydání z roku 1613 (revize od Jana Karafiáta z roku 1920 se neujala). ${ }^{34}$ Pro úplnost dodejme, že v katolické církvi byl na počátku 20. století rozširřený moderní biblický překlad Jana Ladislava Sýkory a Jana Hejčla z let 1913-1925, ${ }^{35}$ církev českobratrská evangelická pak stála za novozákonním překladem prof. Františka Žilky z roku 1933, který nicméně nalezl větší oblibu spíše v mladé československé církvi. ${ }^{36}$

33 Antonín Chráska (1868-1953) byl výjimečně jazykově nadaný. Teologii studoval v německém Neukirchenu (1889-1893) a skotském Glasgowě (1893-1895). Tam se seznámil se Slovinci a začal se připravovat na službu misionáře mezi nimi, v letech 1904-1922 aktivně působil ve Slovinsku. Pracoval na překladu bible do slovinštiny, v Lublani také vydával časopis Blagovestnik (1905-1914). Jeho biblický překlad (vyšel poprvé v Lublani 1914 péčí Biblické společnosti britické a zahraniční) byl teprve druhou jednosvazkovou edicí celého Písma ve slovinštině (první byla Bible Dalmatinova z r. 1584). Srov. DVOŘÁČEK, Bohumil. Z galerie osobnosti Nového Města nad Metuji. Nové Město nad Metují: Městská knihovna, 2008, s. 101-105.

34 Jan Karafiát s Heřmanem z Tardy se pokoušeli navrhnout textovou i jazykovou revizi Bible Kralické již od osmdesátých let 19. století. Hmatatelný výsledek byl znát až v roce $1920 \mathrm{~s}$ vročením 1915 (tj. k pětistému výročí upálení M. Jana Husa). Srov. BARTOŇ, Josef. Moderní český novozákonni preklad. Nové zákony dvacátého stoleti pred Českým ekumenickým překladem. Praha: Česká biblická společnost, 2009, s. 103.

35 Napjaté vztahy s katolickou církví ilustruje emotivní citát zřejmě Františka Urbánka: „Žijeme v době, kdy velká církev se chlubí svojí jednotou a mocí - ona jediná může býti autoritou, o kterou se opírají lidé - proč nám vzdor toho nemůže uškodit? Protože máme tuto knihu. Nic se nebojím církve, která se neshromažd'uje kolem slova živého Boha." Výroční zpráva 1939. In Kniha zápisů ČBP.

36 Srov. BARTOŇ, Josef. Moderní český novozákonní překlad, s. 105. 
„Do těchto dnů knižní trh zásobovaly českým vydáním bible zahraniční společnosti. Tu se odhodlala opět malá náboženská společnost, nesoucí jméno své středověké předchůdkyně - Jednota bratrská - k pietnímu vydání textu Kralické bible šestidílné bez poznámek. Krásný tento počin nutno kvitovati s krajním porozuměním a radostí, že na české půdě do-

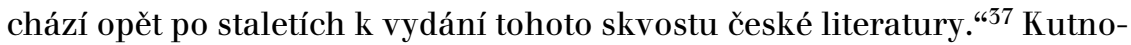
horští tedy sáhli po textu původní kralické „Šestidílky“ z let 1579-1593.38 Pro tuto variantu hovořil i fakt, že výkladové poznámky k tomuto vydání byly již dříve vydány Josefem Kostomlatským v roce $1885 .^{39}$

Usnesení z jednání ze dne 3. března 1940 hovoří: „Česká Bible byla dosud vydávána pomocí zahraničních křestanů. Dávno jsme toužili vydati Bibli z prostředků křest́anů českých. “40 Byla vytvořena redakce ve složení František Urbánek, Antonín Chráska a dr. Pavel Chráska. Při dalších vydáních byli přizváni ke spolupráci i jiní odborníci. Zejména po jazykové stránce pomáhali bohemisté prof. Pavel Váša, prof. František Oberpfalcer a básník dr. Samuel Verner. ${ }^{41} \mathrm{~S}$ ohledem na válečnou dobu a možnosti je velmi obtížné hovořit o přesných počtech vydaných biblí. Zprvu mohlo být vytištěno 40000 knih. $^{42} \mathrm{~V}$ roce 1942 vyšla bible v nákladu 25000 kusů a dva roky na to $\mathrm{v}$ dalších 20000 kusech. $\mathrm{V}$ roce 1944 bylo rozhodnuto o třetím vydání. ${ }^{43} \mathrm{Za}$ dobu fungování ČBP bylo vydáno téměř 80000 výtisků biblí a 10000 samostatných Nových zákonů. ${ }^{44}$ Všechny edice byly bez poznámkového aparátu, s jeho zařazením se počítalo později. ${ }^{45}$

37 ZELINKA, Timoteus Čestmír. Nové vydáni Bible kralické (novinový výstřižek), fČBP.

38 Poslední díl je na titulní straně datován 1593, ale vydán byl až v druhé polovině roku 1594. Srov. KYAS, Vladimír. Česká bible v déjinách národního písemnictví. Praha: Vyšehrad, 1997, s. 186.

39 KOSTOMLATSKÝ, Josef. Výklady starého zákona bibli Kralické šestidílné. Tábor, 1885.

40 Zápis ze schůze dne 3. března 1940. In Kniha zápisů ČBP.

41 Pavel Váša (1874-1954), zprvu středoškolský profesor v Praze, později vyučující bohemistiky na filozofické fakultě v Brně. Student slovanského semináře Jana Gebauera. Dlouholetý redaktor Lidových novin (1917-1937). Zabýval se také folkloristikou. Společně s Františkem Trávníčkem připravil a vydal rozsáhlý Slovník spisovné češtiny (1934-1937). František Oberpfalcer (1890-1973), profesor bohemistiky v Praze. Člen redakční rady časopisu Naše řeč (1932-1948). Zabýval se dějinami českého jazyka a mj. jihočeským a podkrkonošským nářečím. Zdůrazňoval etickou a estetickou stránku jazyka.

42 Biblí 15 000, Nových zákonů 10 000, evangelií 15000 kusů. Srov. Zpráva ze dne 12. prosince 1942. In Kniha zápisů ČBP. Cena prvního vydání bible byla stanovena na $50 \mathrm{~K}$.

43 Srov. Zápis ze schůze dne 19. února 1944. In Kniha zápisů ČBP.

44 Srov. Kronika Biblického ústavu, s. 14.

45 V rukopisech nalezneme korektury textu Bible kralické včetně doplněných vysvětlujících poznámek (cca jedna poznámka na stránku). 


\section{Nový překlad Josefa Berky}

Po úspěšném zaplnění mezery nedostatku biblí pro širokou veřejnost vzešla myšlenka na zcela nové překladatelské dílo. Moderních novozákonních překladů, jak již bylo řečeno výše, bylo povícero. Avšak o překlad starozákonních knih se pokusila pouze katolická církev, v pracích prof. Jana Hejčla (1913-1925) a prof. Josefa Hegera (1934-1947). Velmi zajímavý počin byl pak také bezkonfesijní a výhradně filologický překlad Vladimíra Šrámka (1947-1951). ${ }^{46}$ Moderní překlad Starého zákona z původních jazyků reflektující evangelickou tradici tedy chyběl. Zdeněk Koukol napsal: „Nový překlad jsme vydali proto, že jsme slyšeli od mnohých, kteří byli vychováni v katolictví neb bez vyznání, kteří tedy nebyli vychováni biblí Kralickou, že Kralickému textu dobře nerozumějí. “47 Nový překlad měl být jasný, srozumitelný modernímu člověku. Dle samotného překladatele však neměl nahradit úctyhodnou Bibli kralickou. ${ }^{48}$

Práce na prvním svazku Genesis byla zadána berounskému učiteli PhDr. Josefu Berkovi. Jako metodu si zvolil kritické porovnávání hebrejského originálu s Biblí kralickou. ${ }^{49}$ Co se týče češtiny, chtěl se držet Slovníku spisovné češtiny F. Trávníčka a P. Váši. S druhým jmenovaným dokonce na překladu spolupracoval i úžeji. ${ }^{50} \mathrm{~V}$ ř́jnu 1944 připravil prvních šest kapitol. Blízký spolupracovník ČBP Josef Štifter, sám překlada-

46 Souhrnně k biblickým překladům vzniklým ve dvacátém století viz BARTOŇ, Josef. Století moderního českého biblického překladu (1909-2009). Listy filologické 2010, roč. 133 , s. 53-77.

Dopis od Zdeňka Koukola ze dne 3. března 1947, fČBP.

48 Srov. BERKA, Josef. Úvod. In První kniha Mojžíšova (Genesis). Kutná Hora: Česká biblická práce, 1945.

49 V rukopisu uvádí Josef Berka použitou literaturu: kritické vydání hebrejského originálu (KITTEL, Rudolph. Biblia Hebraica. 2. vydání. Leipzig, 1909), české biblické překlady (Bible kralická 1579-1593 i 1613), tři německé překlady (MENGE, Hermann. Die Heilige Schrift Alten und Neuen Testaments. 7. vydání. Stuttgart, 1931; LUTHER, Martin. Schülerbibel. Stuttgart, 1938; Die Heilige Schrift. Aus dem Grundtext übersetzt. 10. vydání. Wuppertal-Elberfeld, 1934), anglický překlad (nelze přesně určit, snad se jedná o The Holy Bibel. London, 1903), hebrejsko-německý židovský překlad Tóry (MENDELSSOHN, Moses. Berlin, 1783), vedle jiných slovníků J. Berka uvádí klasický Geseniův (GESENIUS, Wilhelm. Hebräisches und Aramäisches Handwörterbuch über das Alte Testament, Leipzig, 1921).

50 Srov. Dopis od Josefa Berky ze dne 30. října 1944, fČBP. Srov. Dopis od Pavla Váši ze dne 7. listopadu 1944, fČBP. - Pro zajímavost uved'me, že 20. listopadu 1944 proběhlo nejtěžší bombardování Brna a prof. Váša o této zkušenosti píše: „Brno mělo v pondělí ošklivý den; ztráty jsou veliké, na některých místech domy hoří. [...] V této zlé době nás zvláště potěšilo dnešní sv. čtení z 2 Kor 5,1. “Dopis od Pavla Váši ze dne 23. listopadu 1944, fČBP. (Zmíněný citát zní: „Víme přece, že bude-li stan našeho pozemského života stržen, čeká nás příbytek od Boha, věčný dům v nebesích, který nebyl zbudován rukama.") 
tel $\mathrm{z}$ angličtiny a švédštiny, byl z těchto prvotin nadšen. ${ }^{51}$ Doporučoval však, aby potřebné výkladové poznámky byly př́padně vloženy do textu až v druhém, upraveném vydání. I když v rukopisech nalezneme všech pět knih Mojžíšových, v roce 1945 vyšel pouze překlad knihy Genesis. Bohužel zájem čtenářủ byl mnohem menší, než se předpokládalo. Dalším plánovaným dílem bylo Proroctví Izaiášovo od Vlastimila Svatopluka Jurena. ${ }^{52}$ Kniha měla být v roce $1947 \mathrm{v}$ tisku. Žádné knihovnické katalogy ji však nikde neuvádějí. Překladatel V. S. Juren pro tisk připravil také Pláč Jeremiášův, Ester, Ruth, Kazatele a Píseň Šalamounovu..$^{53}$

\section{Roháčkův překlad}

V roce 1936 vyšlo u biblické společnosti v Praze první vydání slovenského překladu Písma sv. od prof. Jozefa Roháčka. ${ }^{54}$ Byl to pro tamní nekatolické věřící první pokus nahradit Bibli kralickou. ${ }^{55} \mathrm{~S}$ odstupem nemnoha let bylo v několika přetiscích vydáno více než 120000 kusů biblí i samostatných Nových zákonů. ${ }^{56}$ Předností překladu byla jeho doslovnost. ${ }^{57} \mathrm{Na}$ druhou stranu byla jeho nevýhodou absence jakéhokoli církevního schválení, kterého se však dočkal později. ${ }^{58}$ Velmi ožehavou otázkou byl použitý slovenský pravopis a slovní zásoba (často používal novotva-

51 Srov. Dopis od Josefa Štiftera ze dne 27. října 1944, fČBP. Josef Štifter (1881-1960) byl kazatelem Jednoty českobratrské na Vinohradech. Z angličtiny a švédštiny přeložil několik knih pro mládež. Sestavil také Malou biblickou konkordanci (1. vyd. 1941; 2. vyd. 1953).

Vlastimil Svatopluk Juren (1864-1951) člen českobratrské církve evangelické. Působil jako farář v Hustopečích (1905-1922) a v Lounech (1922-1939). Překládal a psal knihy o M. Lutherovi, J. Kalvínovi nebo dějinách evangelické církve, editor Kancionálu církve reformované (1915).

53 Srov. Dopis Vlastimila Svatopluka Jurena ze dne 25. března 1946, fSCB. Rukopisy však chybí.

54 Jozef Roháček (1877-1962) studoval v Neukirchenu (1898-1903). Kromě řečtiny a hebrejštiny ovládal další čtyři živé jazyky. Spoluprací s obrozeneckým a evangelizačním hnutím Modrý kříž působil v Srbsku a Mad'arsku (1906-1921). Tam, i přes př́sné jazykové zákony, vedl krajanský sbor ve slovenštině. Překlad evangelií dokončil v Nyíregyházy (1910-1911), později v Praze vyšel Nový zákon (1924) a Žalmy (1926). Překlad celé bible vyšel 1936. Tři roky na to podnikl krátkou cestu do Turecka, Řecka, Egypta a Palestiny. V roce 2007 se revidovaný překlad (Kutná Hora, 1951) dočkal již čtvrtého vydání. Srov. MARKUŠ, Štefan. Jozef Roháček. Brána 2007, č. 10, s. 20-21.

Po starším katolickém překladu Juraje Palkoviče (1829-1832) vyšel kolektivní překlad (Andrej Hlinka, Ján Donoval aj.) v letech 1913-1926. Srov. Biblia a jej preklady. $<$ http://sion.profitux.cz/pagina/index.php?page=text\&cislo=5>.

56 Srov. Prof. Jozef Roháček. <http://www.sion.host.sk/rohacek.html>.

57 Což má za důsledek množství grécismů a hebraismů i menší plynulost jazyka.

58 Církví autorizovaný Nový zákon vyšel 1942, celá bible 1978. 
ry). ${ }^{59}$ Dalším nedostatkem Roháčkova překladu byla jeho př́íliš vysoká cena. Přesto byl téměř celý tiskový náklad Písma sv. rozebrán. Nedlouho poté se naskytla možnost připravit druhé vydání s obsahovou i jazykovou revizí. Slovenská církev augsburského vyznání sice pracovala na svém novém překladu, první část vyšla $\mathrm{v}$ roce $1942,{ }^{60}$ knihy Starého zákona však v polovině čtyřicátých let zůstaly v nedohlednu. J. Roháček tedy opět vstoupil do jednání s biblickou společností ohledně revidovaného vydání bible. Důvody, proč jej nakonec v Praze odmítli a jednalo se o vytištění v Kutné Hoře, nám mohou být zřejmější ze vzájemné korespondence.

Karol Vaculík, bratislavský kazatel Jednoty baptistů na Slovensku, se na Zdeňka Koukola obrátil potom, co se dověděl, že biblická společnost upravený slovenský překlad odmítla vydat a údajně se měl tisknout v Kutné Hoře. ${ }^{61}$ Sdělil, že se mu podařilo zajistit tuzemské i zahraniční peníze, aby cena nového vydání bible byla skutečně lidová. ${ }^{62}$ Dále zjistil, že „na br. prof. Roháčka byl z různých míst kladen požadavek, aby dal svůj revidovaný překlad prohlédnout schopným lidem ze stanoviska správné slovenštiny." S touto podmínkou však překladatel nesouhlasil. Pro vydání nového biblického překladu byla proto zřizena zvláštní vyjednávací skupina ${ }^{63}$ Ani potom J. Roháček své stanovisko nezměnil. „Praví, že tam absolutně není co měnit. [...] Raději odmítá jakoukoli podporu a že si vydá Bibli sám, bez pomoci.“ Jediný pokrok byl, když se uvolil ukázat korektorům alespoň již vysázený text. „On pak znovu ujistil, že tato práce je i tak zcela zbytečná, protože překlad je dokonalý a on že se nehodlá řídit proměnlivými pravidly gramatiky."64 Podobně rozporuplné pocity z jednání $\mathrm{s}$ J. Roháčkem měla i další členka pracovní skupiny R. Wärmerová. ${ }^{65} \mathrm{Ve}$ svých odpovědích se i Z. Koukol, který byl s překladatelem v kontaktu od prosince 1946, vyjadřoval velmi opatrně. ${ }^{66}$ Sice věděl o nutnosti tisku nedostatkové slovenské bible, přesto kvůli zachování kvality výtisku nesle-

59 První pravidla spisovné slovenštiny vyšla až roku 1931.

60 Nová smluva. Liptovsky Svätý Mikuláš: Tranoscius, 1942.

61 Můžeme se domnívat, že na odmítnutí mohl mít vliv i tehdejší nedostatek kvalitního papíru či neudělené povolení od státních orgánů. Proto se zřejmě J. Roháček obrátil na mateřskou organizaci biblické společnosti do Londýna. Zde však narazil na další obtíž: tamní sazeči nebyli schopni přečíst rukopis a vysázet slovenský text. Zřejmě po této zkušenosti se obrátil na Scripture Gift Mission v Londýně a teprve potom na ČBP do Kutné Hory. Srov. Dopis od Scripture Gift Mission ze dne 13. ledna 1947, fČBP.

62 Srov. Dopis od Karla Vaculíka ze dne 9. 1. 1947, fČBP.

63 Členy byli prof. Jozef Roháček, Karol Vaculík, Emil Král, Růžena Wärmerová a zřejmě i Zdeněk Koukol.

64 Srov. Dopis od Karla Vaculíka ze dne 9. 1. 1947, fČBP.

65 Srov. Dopis od Růženy Wärmerové ze dne 10. ledna 1947, fČBP.

66 Srov. Dopis od Zdeňka Koukola ze dne 13. ledna 1947, fČBP. Srov. Dopis od Zdeňka Koukola ze dne 17. ledna 1947 
vil od přehlédnutí rukopisu slovenskými jazykovědci. ${ }^{67} \mathrm{~J}$. Roháček však drtivou většinu navržených úprav „šmahem odmítal“ ${ }^{68}$ Za těchto okolností v červnu 1949 skončil roztrpčený Karol Vaculík svojí spolupráci. ${ }^{69}$

Dovolme si ještě předložit několik poznámek $\mathrm{k}$ samotnému textu, jak je nalézáme $\mathbf{v}$ dochovaných archiváliích. Snahou překladatele bylo vytvořit text, u kterého by měl čtenář pocit, že alespoň z $95 \%$ čte originál. ${ }^{70}{ } \mathrm{~V}$ preklade je každej litere, ba i každej čiarke venovaná plná pozornost'. Avšak ked'že je každý človek nedokonalý, nemôže ani jeho dielo byt absolútne dokonalým, a tak zaiste i v tomto diele najdú sa nejaké nedostatky."71 Místy však považoval za nutné se odchýlit od zavedených jazykových norem. ${ }^{72} \mathrm{~A}$ právě tato jazyková nevázanost mu byla později vytýkána. Ve fondu ČBP nalezneme dopis, kterým pisatel dává najevo „zodpovednost' pred budúcimi generáciami“ a ostře Roháčkův překlad kritizuje (celý dopis je psán velmi emotivně a o jeho objektivnosti můžeme mít oprávněné pochyby). ${ }^{73}$ Jen v první kapitole knihy Genesis autor napočítává 30 školáckých chyb, jinde nalézá i nesrozumitelné novotvary. ${ }^{74}$ Př́mou úměrou dochází k výpočtu, že v celém Starém zákoně bude cca 25000 chyb. „Ak by sa takýchto chýb dopúštal žiak 1. roč. strednej školy, neprejde do vyššieho ročníka. “75 $\mathrm{Z}$ tohoto důvodu je tento text pro školní mládež přímo nevhodný. ${ }^{76}$ Důsledkem toho by mohlo být zabavení celého tisku Slovenským úřadem pro věci církevní. „O jedno Vás prosím: nevydávajte slovenskú Bibliu v takomto preklade. Nedovolte prznit našu melodičnú lubozvučnú slovenčinu. Dbajte o to, aby Slovo Božie zvlášt́ tlačou bolo hlásané čiste a nebolo k pohoršeniu. “77

67 Srov. Dopis od Zdeňka Koukola ze dne 13. února 1947, fČBP.

68 Srov. Dopis Zdeňka Koukola zde dne 28. května 1949, fSCB.

69 Srov. Dopis Karola Vaculíka ze dne 23. května 1949, fSCB. „Prof. Roháček ostatně pokud jde o text pomoci nežádá a nepotřebuje. Stereotypně prohlašuje, že text je věcí hotovou, na niž se nedá nic měnit a že tu ani není nikoho k tomu povolaného. [...] Je to dobře zařízené, aby do toho nikdo neviděl." Srov. Dopis Karola Vaculíka ze dne 10. června 1949, fSCB.

70 Srov. ROHÁČEK Jozef. Sprievodné slovo k slovenskému Sv. Písmu. In Svätá Biblia. Kutná Hora: Česká biblická práce, 1951.

71 Tamtéž.

72 Srov. tamtéž.

73 Dopis Jána [...] ze dne 20. října 1949, fSCB.

74 Roháček píše okrýdlené místo okrídlené, Bôh místo Boh. Vyjmenované novotvary uvádím v pořadí: J. Roháček (evangelický překlad). Ž 102,1 vylieval svoju žial'bu (vylieva si žial), Ž 102,27 zvetšejú ako rúcho (sa rozpadne ako odev), Gn 1,20 sa hemžia vody hemživými tvory (sa vody víria pohybom živých tvorov).

75 Tamtéž.

76 „Nuž ak by sme im mali dat takýto preklad, tak radšej nič.“ Tamtéž.

77 Tamtéž. 
Již z tohoto vysvítá, že spolupráce s J. Roháčkem byla pro ČBP velice obtížná. Další komplikace zakoušel Z. Koukol při jednání o vlastním vzhledu jednotlivých stran. Po jednání v polovině roku 1948 byly dohodnuty poslední úpravy před konečným vysázením textu. Půl roku nato se překladatel dožadoval dalších změn. „Je to postup, promiňte, že Vám to řeknu zcela upřímně, velmi nemoudrý. “78 Kvůli dalším nespokojenostem $\mathrm{s}$ jazykovou kvalitou překladu dokonce hrozilo i zastavení tisku. ${ }^{79}$

Potřebné povolení k tisku ČBP získala 19. listopadu $1948{ }^{80}$ Revidované vydání slovenského vydání bible vyšlo nákladem ČBP po více než třech letech $\mathrm{v}$ roce 1951 , a to $\mathrm{v}$ objemu téměř 20000 kusů. ${ }^{81}$ Autora kritiky by zřejmě překvapilo, že tato jazyková verze se dočkala širokého rozšíření a je přetiskována prakticky dodnes. Již popáté ji v roce 2009 vydala Slovenská biblická společnost.

\section{Nikdy nedokončené projekty}

Nedokončeným projektem bylo vydání českého překladu výkladových poznámek německé Jubiläumsbibel. ${ }^{82}$ Výjimečnost této bible nespočívá ani tak v biblickém překladu (revidovaný text Martina Luthera 1534), ale v kvalitním poznámkovém aparátu upraveném Paulem Langbeinem. ${ }^{83}$ Název „Jubilejní bible“ se odvíjí od jejího vydání v roce 1912, tedy u příležitosti stého výročí založení Württemberské biblické společnosti. Nápad vzešel od Josefa Chyby. ${ }^{84} \mathrm{~V}$ předmluvě Nového zákona svoji pohnutku vysvětluje. Jako konvertita byl veden k četbě Písma sv., kterému tehdy nerozuměl. Byl nucen tedy hledat různé pomůcky. Skrovné české spisy mu nedokázaly odpovědět na většinu kladených otázek. Teprve když otevřel Jubiläumsbibel, byl spokojen. První výsledky své

78 Dopis Zdeňka Koukola ze dne 15. ledna 1949, fSCB.

79 Srov. Dopis Zdeňka Koukola zde dne 28. května 1949, fSCB.

80 Srov. Žádost o tisk Bible ze dne 2. února 1951, fSCB.

81 Celkový objem peněz potřebných k vytištění slovenské bible byl téměř 1900000 Kčs.

82 Jubiläumsbibel. Stuttgart, 1912.

83 Paul Langbein (1840-1915) působil jako farář v několika německých městech. Ve svých publikacích se často věnoval výkladům Písma sv.

84 Josef Chyba (1898-1986) byl vyučený zahradník v Langenzersdorfu u Vídně. Během války bojoval od září 1916 do listopadu 1918 na italské frontě, kde byl postřelen do ruky. Při bojích s mad'arskými vojsky byl na Slovensku postřelen do hlavy. Když odešel z armády, navštěvoval biblické kurzy v Praze (1921-1923) a rok byl mimořádným posluchačem evangelické bohoslovecké fakulty v Praze. V létě 1923 nakrátko odjel na misijní školu do Neukirchenu. Působil jako kazatel v Trhové Kamenici (1928-1945) a Veselí nad Lužnicí (1945-1958). Poté se odstěhoval za dcerou do severozápadních Čech. 
práce zaslal ČBP na přelomu let 1944/1945. „S pomocí Páně jde mi to hravě a mám z toho velikou radost a užitek." 85 Celý překlad poznámek Starého i Nového zákona ve fondu ČBP sice nalezneme, o tom, že by vyšel někdy knižně, nemáme zpráv.

Nevydanými zůstaly i dva překlady Bohumily Hejzlarové, dcery kolportéra Samuela Hejzlara. Z angličtiny přeložila životopisné medailonky Dwighta Lymana Woody(ho) a Charlese Grandisona Finney(e).

\section{9. Činnost v letech 1937 a 1938}

Pro ilustraci můžeme zmínit závěry výročních zpráv v pohnuté době let 1937 a $1938 .^{86}$ „Chybělo maličko a zdvihla by se bývala válka v celé Evropě ve vší své hrůze a se všemi svými velkými bolestmi. [...] Vlast naše je zmenšena, máme mnohem méně obyvatel, ale pro rozšiřovatele Slova Božího není méně práce. [...] Práce naše se zatím omezila na země české.“ 687

Bible a jiná biblická produkce se prodávaly v knihkupectvích nebo se rozšiřovaly tzv. kolportáží. Státem povolený kolportér obcházející domy $\mathrm{v}$ jednotlivých městech nesměl prodávat lidem knihy přímo. ${ }^{88}$ Směl s sebou nosit ukázkové výtisky a v př́padě zájmu sepsal objednávku. Tyto kolportéry ČBP v roce 1937 zaměstnávala tři: Josef Matoška projížděl Moravu, Čechy František Všetečka a Jan Francouch Podkarpatskou Rus. Poslední jmenovaný v roce 1938 ukončil spolupráci a naopak byl přijat Samuel Hejzlar jako další kolportér pro Čechy. ${ }^{89} \mathrm{~V}$ dvou letech 1937 a 1938 se mezi (nejen) český lid dostalo 1647 biblí, 59283 Nových zákonů nebo i jednotlivých knih (nejvíce Evangelium podle sv. Jana a Epištola sv. Pavla Římanům). ${ }^{90}$ Dalších knih, brožurek, letáků a plakátů bychom napočítali kolem 63000 .

85 Dopis od Josefa Chyby ze dne 30. ledna 1945, fČBP.

86 Úplné výroční zprávy ze čtyřicátých let se nalézt bohužel nepodařilo.

87 Výroční zpráva ČBP 1938, fČBP, ka. 99. Další údaje viz Výroční zpráva ČBP 1937. In Kniha zápisů ČBP.

88 Srov. zákon $6 / 1862$ ř. z. ze dne 17 . prosince 1862 . $\$ 23$ „Choditi se spisy tištěnými po domech, vyvolávati, rozdávati a prodávati je mimo místnosti řádně k tomu určené, jest zapovězeno, a taktéž zapovězeno jest, sbírati předplatitele nebo upisovatele, nemá-li kdo k tomu povolení písemného, vydaného k tomu zvláště úřadem bezpečnosti.“ Podobná právní úprava byla přijata po roce 1918. Více na Kolportáž.cz-evangelisté, kolportéri, podomni obchodníci. <www.kolportaz.cz>.

89 Ve fČBP máme dochovánu obsáhlou korespondenci mezi Z. Koukolem a S. Hejzlarem. Kolportér v pravidelných dopisech, hlášeních, vyprávěl o zážitcích ze svého náročného života. Jistě se jedná o téma hodné zpracování.

90 Výroční zpráva 1938 udává rozšíření 36374 evangelií a 15140 epištol. 
Hospodaření v roce 1937 skončilo se schodkem 6649 K. V následujícím roce se však díky příspěvkům 142 členů a příznivců přehouplo do kladných čísel (příspěvky a dary se $\mathrm{v}$ tomto roce zdvojnásobily na téměř 60000 K). Více než polovina těchto peněz byla určena na výdaje na „propagátory“ (plat, cestovné, pojištění, korespondence). Obrat celé společnosti se obvykle blížil úctyhodné hodnotě čtvrt milionu korun.

\section{Konec České biblické práce}

Již od poloviny roku 1949 začaly státní orgány klást překážky vydavatelské činnosti ČBP. „Budete-li považovat za nutné vydati nějakou důležitou publikaci, máte kdykoliv možnost obrátiti se na některé kolektivní nakladatelství, ve Vašem př́padě např. na nakladatelství KALICH, Praha II, Jungmannova č. 9.“91 Získat povolení k dotisku však bylo pravděpodobnější. V březnu 1950 přišel od Ústředního národního výboru hlavního města Prahy úřední dopis. Sděluje, že při prohlídce stanov spolků Česká biblická práce a Biblická společnost československá byl shledán „shodný účel a náplň práce“. Proto bylo doporučeno jejich splynutí. ${ }^{92}$ Odpověd' měl dr. Pavel Chráska, předseda ČBP, dát vědět nejpozději 10. dubna $1950 .^{93}$

Dva dny před nejzazším termínem byla odeslána odpověd. Obsáhle vypočítává jednotlivé aktivity spolku. Zároveň se zde dr. Pavel Chráska, jasně vymezuje vůči Biblické společnosti československé. „[BSČ] má za úkol vydávati bible a to bez poznámek a jiné podniky pořádá pouze v zájmu šíření bible. [...] My pracujeme pro mravní povznesení. “94 Dále dodává, že biblická společnost je členem mezinárodní organizace, kdežto ČBP vznikla a je podporována výhradně svými členy a příznivci.

V podobném duchu psal i tajemník biblické společnosti Blahoslav Černohorský v dopise z 15. května 1950. Pět dní před tímto dopisem proběhla schůzka mezi Černohorským a dr. Chráskou se stejným výsledkem. „Biblická společnost nemá jiného účelu a také jinou činnost neprovozuje než vydávání a šíření Kralické bible. [...] Naproti tomu Česká biblická práce [...] má vydání biblí jen jako jeden ze svých mnohých úkolů. “95 Důležitým faktorem byly i církve, které stály za jednotlivými spolky. Činnost biblické spo-

91 Srov. Dokument Ministerstva informací a osvěty čj. 46672/49/III. ze dne 13. srpna 1949, fSCB.

92 Hlavní motivací státu byla teze, aby jakákoli náboženská činnost byla vedena výhradně pod hlavičkou (registrované) církve.

93 Srov. Dopis Ústředního národního výboru hl. m. Prahy - Krajského velitelství Národní bezpečnosti v Praze ze dne 18. březen 1950 (čj. Spol. I-96-2003-1950-V/4), fČBP.

94 Dopis od ČBP ze dne 8. dubna 1950, fČBP.

95 Dopis Státnímu úřadu pro věci církevní ze dne 15. května 1950, fČBP. 
lečnosti byla výsledkem spolupráce devíti církví. ${ }^{96} \mathrm{Jak}$ již bylo řečeno dř́ve, ČBP byla téměř výlučně pod patronací Jednoty českobratrské. Biblická společnost nikdy neplánovala rozšírit svoji působnost, tak jako ČBP. Dalším rozdílem v produkci je samotná Bible kralická. Biblická společnost tiskla dle vydání z roku 1613. Text byl zmíněnými církvemi používán při bohoslužbách, a proto vědomě neobsahoval žádné poznámky nebo výklady textu. Oproti tomu ČBP tiskla odlišné, první vydání z let 1579-1593 s krátkými úvody. Na konci svého dopisu Černohorský doporučuje (raději než splynutí zmíněných dvou biblických spolků) změnu ČBP na odbor Jednoty českobratrské, čímž by se zachovala její evangelizační a misijní činnost.

Nevůle Biblické společnosti československé i České biblické práce ke sloučení však na státní orgány neměla valný vliv. Ústřední národní výbor nadále trval na jejich spojení. ${ }^{97}$ Dalším otálením v jednání by tak hrozilo zrušení ČBP bez jakékoli náhrady. Oba spolky začaly vzájemně studovat své stanovy a hledaly možné cesty. Dne 21 . června 1950 proběhla valná hromada biblické společnosti a jeden z přednesených bodů programu bylo i spojení s ČBP. Kutnou Horu na jednání zastupoval Ing. Bohumil Mikulecký. ${ }^{98} \mathrm{~V}$ jednání spolky sice vstoupily, jasný výsledek však nepadl. Jejich činnost se prakticky nepřekrývala.

Teprve po roce, v květnu 1951, proběhlo další jednání ČBP se Státním úřadem pro věci církevní, př̀i němž již bylo státním aparátem doporučeno splynutí s Jednotou českobratrskou. Dne 25. května 1951 byla o tomto návrhu Rada Jednoty informována a její zástupce byl pozván na valnou hromadu ČBP 2. června. Činnost spolku měla být vedena jako odbor biblické práce. Personální zajištění mělo zůstat shodné. I majetek měl být převeden pod tento nový odbor. Likvidátory spolku byli navrženi dr. Pavel Chráska, Pavel Just a Bohuslav Zrůst. Tento návrh byl na řečené poradě 2 . června 1951 jednomyslně schválen. ${ }^{99} \mathrm{O}$ rozpuštění ČBP informoval dr. Chráska Ústř̌ední národní výbor 14. července, který pak zánik spolku uveřejnil v Úředním listě republiky Československé 19. července 1951 a zároveň ČBP vymazal ze spolkového katastru. ${ }^{100}$

96 Konkrétně B. Černohorský uvádí církev československou, českobratrskou evangelickou, slovenskou evangelickou augšpurského vyznání, slovenskou reformovanou (ve spolupráci s mad'arskou reformovanou), evangelickou augšpurského vyznání na Těšínsku, metodistickou, Jednotu bratrskou a Jednotu baptistů.

97 Srov. Dopis Ústředního národního výboru hl. m. Prahy - Krajského velitelství Národní bezpečnosti v Praze ze dne 26. květen 1950, (čj. Spol. I-96-3805/50-V/4), fČBP.

98 Srov. Dopis JUDr. Bohumila Kejře ze dne 14. června 1950, fČBP.

99 Srov. Zápis z valné schůze 2 . června 1951, fČBP.

100 Srov. Dopis Ústředního národního výboru hl. m. Prahy - Krajského velitelství Národní bezpečnosti v Praze ze dne 15. srpen 1951, (čj. 262-1080/15-51-I/96), fČBP. 
Majetek rušící se ČBP byl převeden na Radu Jednoty českobratrské. $\mathrm{Z}$ několika málo položek vyčteme, že byla převedena hodnota vyšší než 1,25 mil. K. Dvě třetiny z tohoto objemu byla cena vytištěných biblí a př̀ipravených tenkých biblových papírů. Zbytek peněz byl uložen v bankách a u dodavatelů $\mathrm{v}$ pohledávkách.

\section{Závěr}

Kutnohorská Česká biblická práce měla silného misijního a evangelizačního ducha a především tímto pohledem je třeba její dílo hodnotit. Přesto nelze odhlížet ani od odborné úrovně jejích (spolu)pracovníků, zejména dr. Pavla Chrásky. Vydávala množství literatury, která měla být šířena velmi levně nebo př́mo zdarma, a to i v obdobích nouze ve válečné a poválečné době. Veliká část práce, kterou ČBP odvedla, byla vykonána „na dobré slovo“, a nejsou tedy o ní vedeny žádné záznamy. Také vzpomínky pamětníků se někdy v podrobnostech liší. Tento článek proto jistě nezachycuje celý příběh České biblické práce vyčerpávajícím způsobem. Byl jím však snad aspoň zčásti splacen dluh, který církevní historik vủči této dost opomíjené, ale zajímavé kapitole dějin českého biblického překladu právem pocituje.

\section{Seznam tiskovin z produkce ČBP $\mathbf{P}^{101}$}

BOYS, A. M. Cesta spasení, 1933, 1937, 1939

LANYI, Karel Bohuslav. Důležitost a význam Písma sv., 1936 (přeložil prof. dr. K. L.)

STEWART, James Alexander. Proč?, 1936

STEWART, James Alexander. K nebesům!, 1937

SVOBODA, Václav. William Chalmers Burns, 1946

HARRISON, Norman Baldwin. Cesta života, 1947 (přeložil Josef Štifter)

SVOBODA, Václav. Lord Shaftesbury, křestanský lidumil a revolucionářr, 1947

SVOBODA, Václav. R. M. M'Cheyne, 1947

KEVAN, Ernest Frederick. Biblické učeni o Bohu. Stručný prehled s 50 otázkami, 1947

MURRAY, Andrew, Očekávání na Boha, 1948 (přeložil Zdeněk Koukol)

101 Tisky vznikaly ve vysokých nákladech. Často se jednalo o brožurky a letáčky, které byly určeny pro soukromou četbu. Ve velkých knihovnách proto mnoho kutnohorských výtisků nenalezneme. Níže uvedený výčet publikací je proto zatížen mnoha nepřesnostmi. Údaje jsou čerpány z různých pramenů: knihovny, elektronická databáze Česká národní bibliografie, Výroční zprávy ČBP, popř. náhodné zmínky v dopisech ve fondu ČBP. 
WASSERZUG-TRAEDER, Gertrud. Slovo Boži je Boži slovo: svédectvi o inspiraci Bible, 1948 (přeložil K[arel] K[olman])

LINDÉN, Fritz - GUSTAFSSON, Johan. Paprsky. Úvahy na každý den roku, 1945 (přeložil Josef Štifter)

STOTT, John Robert Walmsley. Jediná cesta: výklad Pavlova listu Galatským, 1968

\section{Bible a biblické knihy}

Epištola sv. Pavla Řimanům, 1937

Evangelium podle sepsání s. Jana, 1937, 1940, 1945

Kniha žalmủ, podle posledního vydání Kralického z roku 1613, $1939^{102}$

Kniha Prísloví, text a výklady ve znèní Kralickém z roku 1582, $1940^{103}$

Kniha Žalmù to jest Kniha Chval, podle vydáni Kralického z roku 1582, 1940, $1942^{104}$

Bibli svatá, 1940, ${ }^{105} 1942,{ }^{106} 1944,{ }^{107} 1954^{108}$

Evangelia s. Matouše, s. Marka, s. Lukáše a s. Jana, 1941

Nový zákon Pána a Spasitele našeho Ježiše Krista dle pưvodního vydání 1593, $1941,1942,{ }^{109} 1945^{110}$

Nový zákon Pána a Spasitele našeho Ježiše Krista dle vydáni Kralického 1601, 1941

101 Tisky vznikaly ve vysokých nákladech. Často se jednalo o brožurky a letáčky, které byly určeny pro soukromou četbu. Ve velkých knihovnách proto mnoho kutnohorských výtisků nenalezneme. Níže uvedený výčet publikací je proto zatížen mnoha nepřesnostmi. Údaje jsou čerpány z různých pramenů: knihovny, elektronická databáze Česká národní bibliografie, Výroční zprávy ČBP, popř. náhodné zmínky v dopisech ve fondu ČBP.

102 Zřejmě jediné využití revidovaného překladu z roku 1613.

103 Blíže neurčený počet výtisků byl v bibliofilské úpravě na ručním papíře.

104 Kapesní vydání.

105 Plánovaný náklad 15000 kusů. Srov. Zápis ze schůze dne 3. února 1940. In Kniha zápisů $\breve{C B P}$.

106 Druhé upravené vydání v kapesním formátu. Vydáno k jubileu 350 let od narození J. A. Komenského.

107 Třetí vydání vytištěno ve větším formátu. Dotisk tohoto vydání v roce 1946. Srov. Výroční zpráva 1947. In Kniha zápisů ČBP.

${ }^{108}$ Vydáno v Praze: Ústřední církevní nakladatelství, edice Blahoslav. Jubilejní vydání vycházející z vydání 1940 a 1944 (v Předmluvě mylně 1945), včetně Apokryfů 1952. V Předmluvě čteme: „Jest dílem veliké lásky a péče vydavatelské i podpory se strany odpovědných činitelù našeho lidově demokratického státu, kteří tím vycházejí vstříc náboženské potřebě věřící části českého lidu; v mračnech nově hrozících bouří válečných jest i tento čin znamením našeho úsilí o mír, o jehož možném zabezpečení jsme pevně přesvědčeni a pro nějž z hlubin opravdové své víry společně všichni pracujeme.“ Vydání připravili dr. Pavel Chráska, historik dr. Miloslav Kaňák (1917-1985) a další spolupracovníci.

109 Kapesní vydání.

110 Úvod k Matoušovu evangeliu je v Evangeliich (1941) obsáhlejší než v Novém zákoně (1945). 
Genesis. Prvni kniha Mojžišova, 1945 (přeložil dr. Josef Berka)

Evangelij po Sv. Lukežu, 1945 $5^{111}$ (přeložil Antonín Chráska)

Evangelie ot sv. Ioanna, $1945^{112}$ (rusky)

Novi Zakon našega Gospoda in Zveličarja Jezusa Kristusa, 1946 (přeložil Antonín Chráska)

Evangelium s. Lukáše, $1947^{113}$ (s poznámkami)

Nový Zákon nášho Pána a Spasitela Ježiša Krista. Z gréckeho jazyka preložený na slovenský. Znovu revidované vydání, 1949 (přeložil Jozef Roháček)

Kniha Žalmov. Z hebrejského jazyka preložené na slovenský. Znovu revidované vydání, 1949 (přeložil Jozef Roháček)

Svätá Biblia, 1951 (revidované vydání, přeložil Jozef Roháček)

Apokryfy. Bibli české díl pátý z roku 1588, 1952 114

\section{Letáky a brožury}

[anonym]: Bible pripodobnèna velkolepé budové

[anonym]: Božie posolstvo k Tebe. každodenné otázky zodpovedané Bibliou

[anonym]: Budu večereti s Kristem

[anonym]: Bůh mluvil, 1933, 1938

[anonym]: Cesta k nebesům!

[anonym]: Čisté srdce

[anonym]: Jediné východisko ze tmy, 1938

[anonym]: Láska ke Kristu, jak vznikne, jak zanikne a jak znovu vzplane

[anonym]: Můj slib

[anonym]: Nepripodobrujute se

[anonym]: Polnice

[anonym]: Poradili ste sa s Vel'kým Lekárom?

[anonym]: Proč a jak čisti Bibli?

[anonym]: Slova potěšení, více vydání 1938-1947115

[anonym]: Svédectvi Boži pro Tebe (slovenský překlad God's Message to You)

[anonym]: Veliké spaseni

[anonym]: Zaslíbeni o př́chodu, životé, obèti a slávě Pána Ježíše Krista

DONNER, D[...]. Kde je Bůh?

DOSTÁL, Pravdomil Enoch. „Váš hř́ch vás najde!“

FRANC, Josef. Kudy a kam?

\footnotetext{
111 Reprint vydání Biblické společnosti britické a zahraniční v Lublani, 1914.

112 ČBP darovala 1000 kusů této publikace chudým pravoslavným obcím, zvláště na Slovensku. Za dar vřele děkuje vladyka Jelevferij, pravoslavný arcibiskup pražský a český a exarcha Moskevské patriarchie v ČSR, v dopise ze dne 7. května 1947. Srov. Dopis Eparchiální rady pravoslavné církve ze dne 7. května 1947, fSCB.

${ }^{113}$ Blíže neurčený počet výtiskủ byl v bibliofilské úpravě na ručním papíre.

114 Vydáno v Praze: Rada Jednoty českobratrské.

115 Slova potěšení vyšla v roce 1939 v nákladu 25000 kusů. Celkově jich ČBP vydala kolem půl milionu. Srov. Kronika Biblického ústavu, s. 14. Brožurky vycházely v různých jazykových mutacích (např. rusky).
} 
URBÁNEK, František. „A Vy ho neznáte?“

URBÁNEK, František. Slovo pravdy

URBÁNEK, František. Vzpomínáte?

URBÁNEK, František. Zdravé tèlo - zdravá duše

Pavel Jäger (1983), doktorand KTF UK

\section{ABSTRACT \\ PAVEL JÄGER \\ Czech Biblical Work in Kutná Hora}

The article presents an initiative arisen in the milieu of a small evangelical church Unity of Czech Brethren (Brethren Church since 1967). It was a Czech Biblical Work in the town of Kutná Hora which in a short period developed a remarkable activity in publishing bibles and in propagating the Gospel in the Czech lands and partly also abroad.

Key words

Czech Biblical Work, editions of the Czech Bible, Slovene Bible translation 